\title{
Establishing the Nitrogen Dilution Curve for Potato Cultivar Bintje in Belgium
}

\section{F. Ben Abdallah, M. Olivier, J. P. Goffart \& O. Minet}

\section{Potato Research}

Journal of the European Association for Potato Research

ISSN 0014-3065

Volume 59

Number 3

Potato Res. (2016) 59:241-258

DOI 10.1007/s11540-016-9331-y
2016 VOLUME 59/ NUMBER 3

ISSN 0014-3065

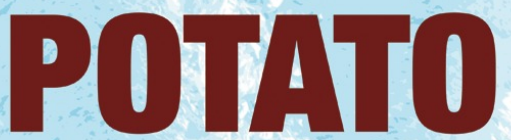

JOURNAL OF THE EUROPEAN ASSOCIATION FOR POTATO RESEARCH
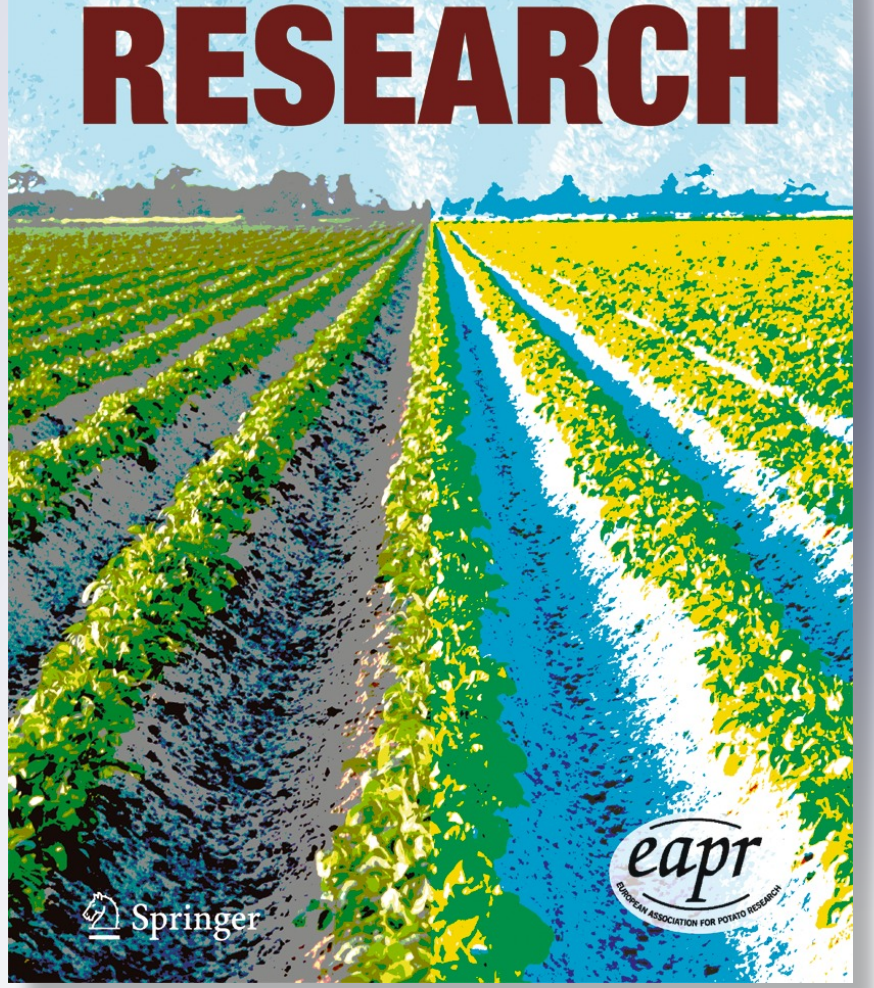
Your article is protected by copyright and all rights are held exclusively by European Association for Potato Research. This eoffprint is for personal use only and shall not be self-archived in electronic repositories. If you wish to self-archive your article, please use the accepted manuscript version for posting on your own website. You may further deposit the accepted manuscript version in any repository, provided it is only made publicly available 12 months after official publication or later and provided acknowledgement is given to the original source of publication and a link is inserted to the published article on Springer's website. The link must be accompanied by the following text: "The final publication is available at link.springer.com". 


\title{
Establishing the Nitrogen Dilution Curve for Potato Cultivar Bintje in Belgium
}

\author{
F. Ben Abdallah ${ }^{1}$ • M. Olivier ${ }^{1}$ - J. P. Goffart ${ }^{1}$. \\ O. Minet $^{2}$
}

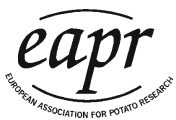

Received: 11 March 2016 / Accepted: 27 September 2016 /

Published online: 20 October 2016

(C) European Association for Potato Research 2016

\begin{abstract}
The nitrogen nutrition index (NNI) is recognized as a reliable plant-based method for diagnosing the crop nitrogen status (CNS). The NNI is based on the concept of critical nitrogen $(\mathrm{Nc})$ dilution curve describing the Nc concentration in the whole plant as a function of the total crop biomass (W). The objectives of this study were (i) to establish the specific potato Nc dilution curve for cv. Bintje under Belgian growing conditions; (ii) to assess if the established curve for cv. Bintje could be used for cv. Charlotte; (iii) to compare the established curve with the existing Nc potato curves; and (iv) to assess the possibility of using the obtained Nc curve to evaluate the potato CNS and to predict the final yield. Field experiments studying increasing nitrogen $(\mathrm{N})$ rates were conducted at different locations in Belgium for several years. Biomass $\mathrm{N}$ concentration and $\mathrm{W}$ production were determined at different sampling dates, and the final tuber yield was determined at harvest. At a sampling date, the Nc was determined by selecting the data point from the treatment presenting the highest W. The NNI was calculated as the ratio between the measured $\mathrm{N}$ concentration in $\mathrm{W}$ and the predicted $\mathrm{Nc}$ according to the $\mathrm{Nc}$ dilution curve. The $\mathrm{Nc}$ curve $\left(\mathrm{Nc}(\%)=5.37 \mathrm{~W}^{-0.45}\right)$ was developed for potato for cv. Bintje under Belgian conditions matching also for $\mathrm{cv}$. Charlotte. The Belgian Nc curve presented similar values as the curves developed previously in Scotland and the Netherlands. NNI was related to relative tuber yield (ratio between the tuber yield obtained for a given $\mathrm{N}$ rate and the highest tuber yield obtained among all $\mathrm{N}$ application rates). The Nc curve and the NNI adequately identified situations of limiting and non-limiting $\mathrm{N}$ nutrition and could be used to establish the potato CNS and to predict the final yield.
\end{abstract}

\section{F. Ben Abdallah \\ f.benabdallah@cra.wallonie.be}

1 Production and Sectors Department, Crops Production Systems Unit, Walloon Agricultural Research Centre (CRA-W), Gembloux, Belgium

2 Valorisation of Agricultural Products Department, Food and Feed Quality Unit, Walloon Agricultural Research Centre (CRA-W), Gembloux, Belgium 
Keywords Critical nitrogen dilution curve $\cdot$ Crop nitrogen status $\cdot$ Nitrogen nutrition index $\cdot$ Plant-based method $\cdot$ Potato

$\begin{array}{ll}\text { Abbreviations } \\ \text { CNS } & \text { Crop nitrogen status } \\ \text { DM } & \text { Dry matter } \\ \text { Nc } & \text { Critical nitrogen } \\ \text { NNI } & \text { Nitrogen nutrition index } \\ \text { RY } & \text { Relative yield } \\ \text { W } & \text { Total biomass }\end{array}$

\section{Introduction}

Plant-based diagnosis methods can be used to improve the efficiency of nitrogen $(\mathrm{N})$ fertilizers use and reduce the risks of $\mathrm{N}$ losses to the environment. The nitrogen nutrition index (NNI) is recognized as a reliable, plant-based method for diagnosing the crop N status (CNS) (Justes et al. 1994; Bélanger et al. 2001; Ziadi et al. 2008; Lemaire and Gastal 2009; Li et al. 2012). The NNI was proposed to quantify the intensity of both $\mathrm{N}$ deficiency and luxury consumption of a given crop (Justes et al. 1994; Lemaire and Gastal 1997) and to establish its N requirements (Giletto and Echeverría 2012). The NNI is calculated as the ratio between the plant $\mathrm{N}$ concentration and the critical $\mathrm{N}(\mathrm{Nc})$ concentration. The Nc concentration is defined as the minimum plant $\mathrm{N}$ concentration allowing maximum shoot biomass (Ulrich 1952). The concept of an Nc curve based on the $\mathrm{N}$ concentration in whole plants was first developed by Lemaire and Salette (1984) for tall fescue (Festuca arundinacea Schreb.) and has been successfully applied to many crops including wheat (Triticum aestivum L.) (Justes et al. 1994; Ziadi et al. 2010), corn (Zea mays L.) (Plénet and Lemaire 2000; Ziadi et al. 2008), rapeseed (Brassica napus L.) (Colnenne et al. 1998), rice (Oryza sativa L.) (Sheehy et al. 1998) and potato (Solanum tuberosum L.) (Greenwood et al. 1990; Duchenne et al. 1997; Bélanger et al. 2001; Giletto and Echeverría 2012). The Nc is represented by an allometric function:

$$
\mathrm{Nc}(\%)=a \mathrm{~W}^{-b}
$$

where $\mathrm{W}$ is the total biomass expressed in tons $(\mathrm{t})$ of dry matter (DM) ha ${ }^{-1}$, Nc is the total $\mathrm{N}$ concentration in the plant expressed in grams per $100 \mathrm{~g}$ of DM (\%), and $a$ and $b$ are parameters to be estimated (Bélanger and Gastal 2000). The parameter $a$ represents the $\mathrm{N}$ concentration at a total biomass of $1 \mathrm{t} \mathrm{DM} \mathrm{ha}{ }^{-1}$, and $b$ represents the coefficient of dilution which describes the relationship of decreasing $\mathrm{N}$ concentration with increasing W. In potato, due to the strong effect of $\mathrm{N}$ nutrition on the partitioning of DM between shoots and tubers, the values of $a$ and $b$ are estimated using the combined biomass of shoots and tubers and the corresponding $\mathrm{N}$ concentration of this combined biomass (Duchenne et al.1997; Bélanger et al. 2001; Giletto and Echeverría 2012).

For potato, parameters $a$ and $b$ were reported for different cultivars and under different pedo-climatic conditions. Greenwood et al. (1990) reported values of $a=5.36$ and $b=0.46$ for cultivar (cv.) Voran and cv. Eigenheimer (data from 
Scotland and the Netherlands); Duchenne et al. (1997) reported values of $a=5.21$ and $b=0.56$ for cultivars Bintje, Kaptah Vandel, Russet Burbank and Saturna (data from France); Bélanger et al. (2001) reported values of $a=5.04$ and $b=0.42$ for cv. Shepody and values of $a=4.57$ and $b=0.42$ for cv. Russet Burbank (data from Canada); and Giletto and Echeverría (2012) reported values of $a=5.30$ and $b=0.42$ for cv. Innovator (data from Argentina). For biomass less than $1 \mathrm{t} \mathrm{ha}{ }^{-1}$, Nc takes a constant value due to its small decline with increasing W (Justes et al. 1994) and the lack of competition for light of isolated plants (Lemaire and Gastal 1997). For potato, Duchenne et al. (1997) reported a constant value for $\mathrm{W}$ less than $1.35 \mathrm{t} \mathrm{ha}^{-1}$ which coincides with the beginning of competition between plants for light and also with the time of tuber initiation. Greenwood et al. (1990), Duchenne et al. (1997) and Giletto and Echeverría (2012) based their estimation of the Nc curve on data with a range of W up to $12-$ $15 \mathrm{t} \mathrm{ha}^{-1}$. Bélanger et al. (2001) selected $\mathrm{W}$ ranging from 1 to $6 \mathrm{t} \mathrm{DM} \mathrm{ha}^{-1}$ to avoid measurements with senescence towards the end of the growth cycle.

To our knowledge, no critical curve was established in Belgium for the potato crop. The objectives of this study were (i) to establish the specific potato Nc dilution curve for $\mathrm{cv}$. Bintje under Belgian growing conditions; (ii) to verify if the established curve for Bintje could be used for cv. Charlotte; (iii) to compare the established curve with the existing Nc curves for potato established in other countries; and (iv) to assess the possibility of using the obtained Nc curve to evaluate the potato CNS and to predict the final yield.

\section{Materials and Methods}

\section{Field Experiments}

Experiments in various regions of Belgium were used to estimate the Nc curve. These experiments consisted of several previous trials implemented in the framework of larger studies conducted at the Walloon Agriculture Research Centre (from 1997 to 2000, in 2004 and from 2010 to 2014). Trials included two cultivars: Bintje and Charlotte. Cultivar Bintje was chosen as it is the most important cv. in Belgian agriculture. In order to verify if the established curve could also be used for other cultivars with shorter growing season, cv. Charlotte was also used in this study as it has an early growing cycle compared to mid-early growing cycle for Bintje. Table 1 summarizes the site characteristics of the experiments. The experimental design for the period 1997-2010 was a randomized block scheme with increasing N-fertilizer rates. From 2011 to 2014, the design was a split-plot block scheme with cultivars Bintje and Charlotte as main plots and $\mathrm{N}$ rates as sub-plots. Ammonium nitrate fertilizer (solid granules, $27 \% \mathrm{~N}+$ $4 \% \mathrm{MgO}$ ) was broadcasted and incorporated just before planting. Phosphorus (P) and potassium $(\mathrm{K})$ fertilizers were applied before planting at rates around $70-80 \mathrm{~kg} \mathrm{P}_{2} \mathrm{O}_{5}$ $\mathrm{ha}^{-1}$ and $250-300 \mathrm{~kg} \mathrm{~K}_{2} \mathrm{O} \mathrm{ha}{ }^{-1}$. Trials were rain fed, and no period of significant drought stress was observed for those trials.

\section{Analytical Methods}

Plant samples were collected for all the sites for different sampling dates (except for the site Roisin 2000 for which there was only one sampling date) (Table 1). Eight plants per 


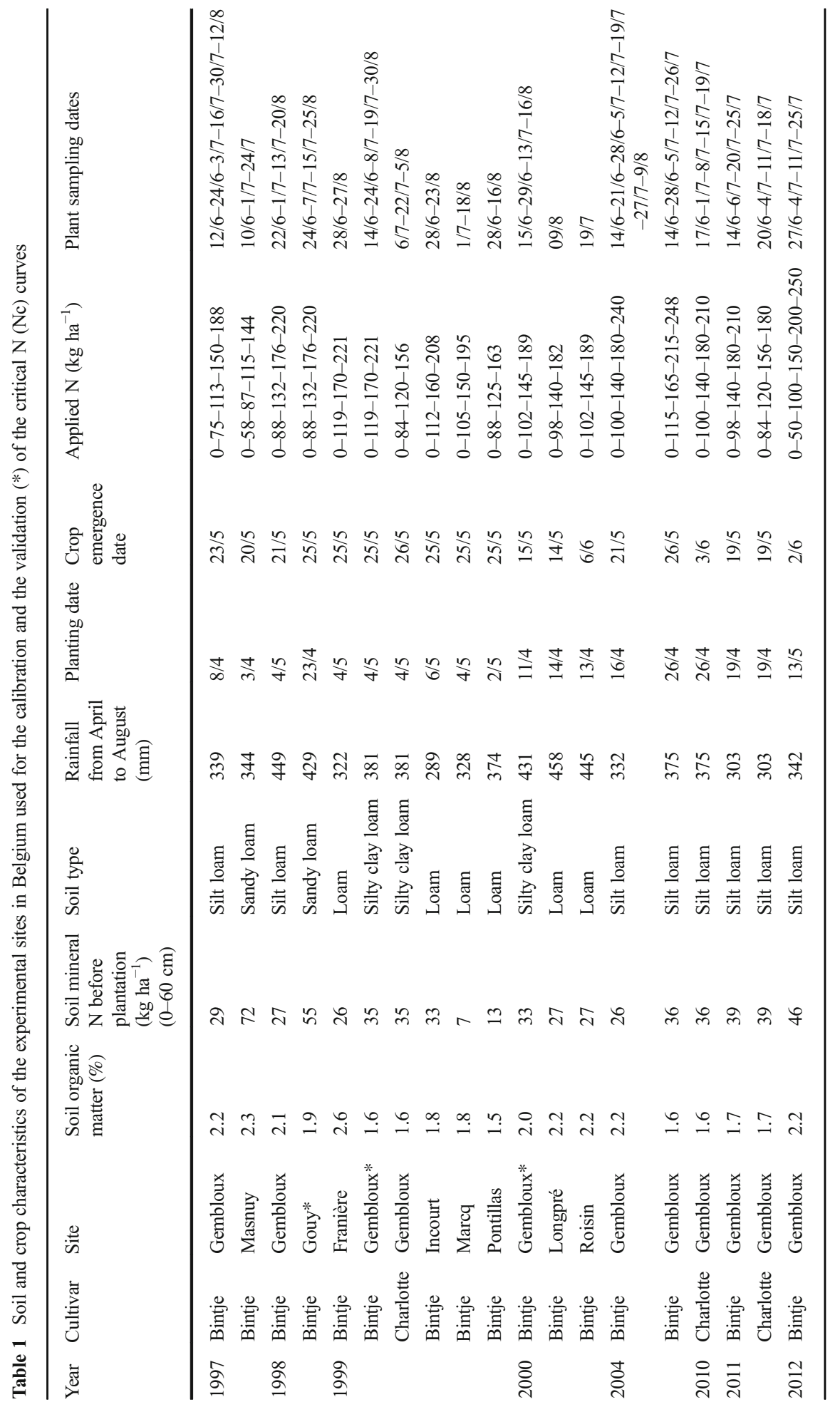




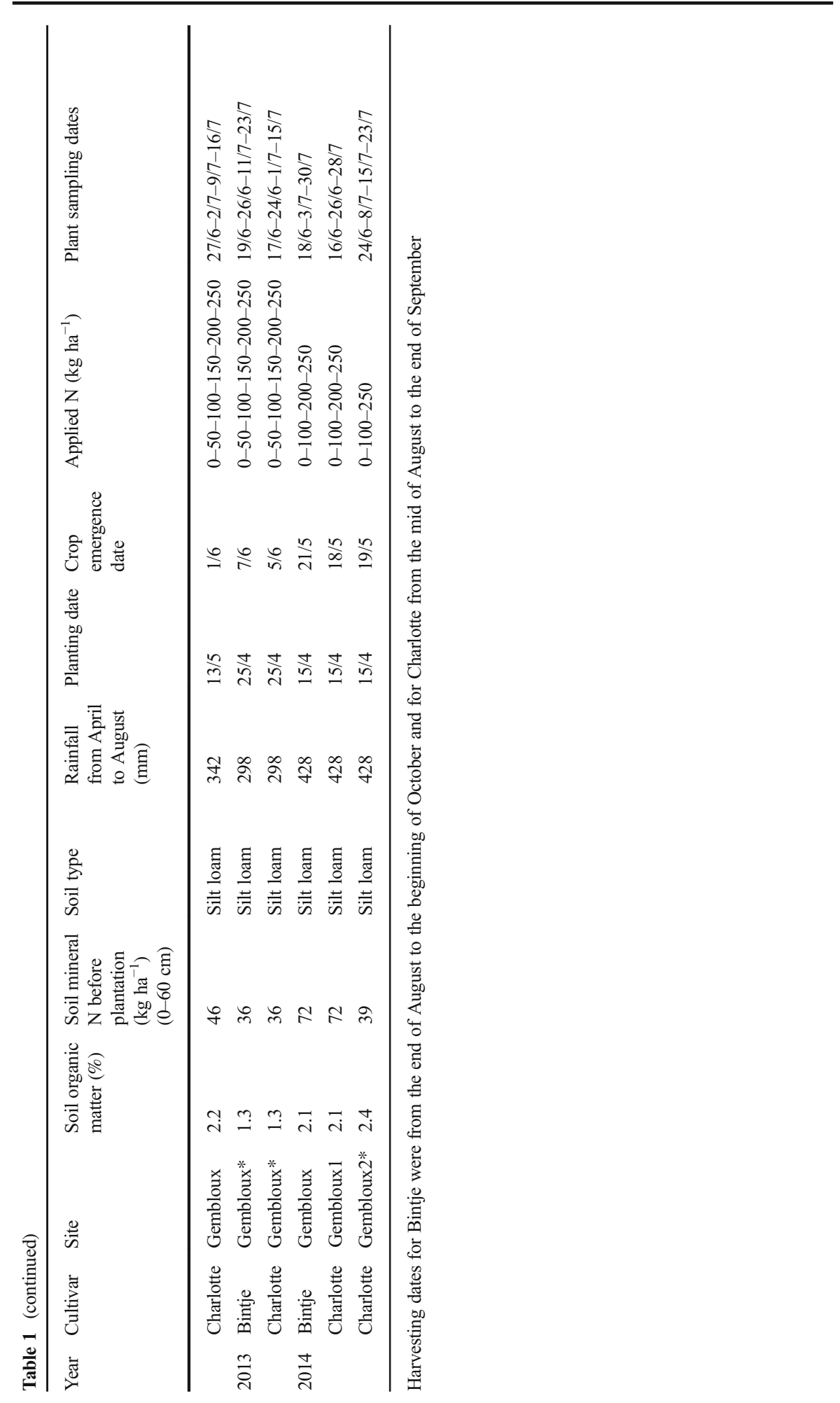


plots were collected and taken to the laboratory. The harvested plots were spaced out to avoid the influence of the previous sample collection. The plants were washed, air dried and weighed in order to determine separately the shoots (leaves + stems) and tubers' fresh weights. Sub-samples of each plant part were then dried at $80{ }^{\circ} \mathrm{C}$ up to constant dry weight. The DM concentration of each sample was then calculated. W was calculated by adding the shoot biomass and tuber DM. The dried samples of shoots and tubers were finely crushed with a Cyclotec 1093 sample mill (FOSS, Tecator). The $\mathrm{N}$ concentration in shoots and tubers was determined with near-infrared (NIR) spectroscopy using a FOSS-NIR Systems 6500 scanning instrument (NIR-Systems, Silver Springs, MD) and calibrated using the Dumas combustion method (LECO, St. Joseph, MI, USA) and the statistical method developed by Shenk and Westerhaus (1993). The $\mathrm{N}$ concentration $(\% \mathrm{~N})$ in $\mathrm{W}$ was calculated as

$$
\% \mathrm{~N}=\frac{\left(\% \mathrm{~N}_{\text {shoots }} \times \mathrm{W}_{\text {shoots }}\right)+\left(\% \mathrm{~N}_{\text {tubers }} \times \mathrm{W}_{\text {tubers }}\right)}{\mathrm{W}}
$$

where $\% \mathrm{~N}_{\text {shoots }}$ and $\% \mathrm{~N}_{\text {tubers }}$ are the $\mathrm{N}$ concentrations in shoots and tubers respectively, expressed in grammes per $100 \mathrm{~g}^{-1}$ of DM. W is the total biomass in $\mathrm{t} \mathrm{DM} \mathrm{ha}^{-1}$, $\mathrm{W}_{\text {shoots }}$ is the shoot biomass in $\mathrm{t} \mathrm{DM} \mathrm{ha}{ }^{-1}$ and $\mathrm{W}_{\text {tubers }}$ is the tuber biomass in $\mathrm{t} \mathrm{DM} \mathrm{ha}{ }^{-1}$.

\section{Data Processing}

The collected data set for $\mathrm{cv}$. Bintje was divided in a calibration and a validation data set (Table 1).

The calibration of the Nc curve requires the identification of data points for which $\mathrm{N}$ does not limit crop growth. Therefore, a procedure was used similar to Greenwood et al. (1990) as Duchenne et al. (1997), Bélanger et al. (2001), Ziadi et al. (2008), Giletto and Echeverría (2012) and Li et al. (2012) did. At each sampling date, for cv. Bintje, W and total biomass $\mathrm{N}$ concentration were analysed by analysis of variance $(F$ test) and the LSD test (SAS 9.4). Sampling dates were not used for the determination of the Nc curve when the $F$ value indicated no significant difference $(p \leq 0.05)$ of $\mathrm{W}$ among the $\mathrm{N}$ application rates. For the remaining sampling dates, the significantly highest $\mathrm{W}$ obtained with any level of fertilizer and the corresponding $\mathrm{N}$ concentration $(\%)$ were identified using the LSD test $(p \leq 0.05)$. These data points were used for the establishment of the Nc curve. Where the highest $\mathrm{W}$ was obtained with more than one $\mathrm{N}$-fertilizer level, the data obtained with the lower $\mathrm{N}$ level was selected for the establishment of Nc curve. Only data with $\mathrm{W}$ higher than $1 \mathrm{t} \mathrm{DM} \mathrm{ha}{ }^{-1}$ were used for the calibration of Nc curve. The set of data was limited to the period of June and July (period between 20 and 70 days after emergence (DAE)) to avoid including measurements in the senescence period corresponding to the end of the growth cycle. The parameters of Nc curve in Eq. (1) were obtained using the SAS non-linear regression procedure (PROC NLIN). Pseudo- $R^{2}$ was used to assess model fit with the SAS non-linear procedure (Brook et al. 2008).

The validation data for $\mathrm{cv}$. Bintje were also classified using the LSD test $(p \leq 0.05)$. For each sampling date, a treatment with significantly lower $\mathrm{W}$ than the $\mathrm{W}$ of the treatment having received higher $\mathrm{N}$ rate was considered to be a limiting $\mathrm{N}$ condition. $\mathrm{A}$ 
treatment with significantly higher $\mathrm{W}$ than the $\mathrm{W}$ of the treatment having received lower $\mathrm{N}$ rate was considered to be a non-limiting $\mathrm{N}$ condition. Treatments were not selected if their $\mathrm{W}$ was classified in more than one group.

For cv. Charlotte, due to the limited number of data points meeting the afore mentioned criteria (only four points), the Nc curve was not established. This set of data was used to verify if the established curve for $\mathrm{cv}$. Bintje could also be used for $\mathrm{cv}$. Charlotte by identifying the limiting $\mathrm{N}$ conditions and the non-limiting $\mathrm{N}$ conditions (LSD test at $p \leq 0.05$ ).

The NNI for Bintje was calculated at each sampling date as the ratio between the measured \% $\mathrm{N}$ concentration in $\mathrm{W}$ (as in Eq. 2) and the predicted \% Nc. The relative yield (RY) was calculated as the ratio of the tuber yield obtained for a given $\mathrm{N}$ rate with the highest tuber yield obtained among all $\mathrm{N}$ application rates.

The relationship between NNI and RY was defined for three periods of the crop growth season. The three functions were estimated using the SAS quadratic plateau procedure (PROC NLIN). The first quadratic function took into account the average of the NNI values across all sampling dates (Ziadi et al. 2010; Li et al. 2012). The second function took into account the average of the NNI values across the period between 20 and 55 days after emergence (DAE). This period corresponds to the optimal period for assessment of CNS as previously stated by Olivier et al. (2006). The third function took into account the NNI calculated for the last sampling dates for each site (dates between 44 and 94 DAE). The last sampling date corresponded to the available one closest to the harvesting date. This third period is similar to that used by Chambenoit et al. (2004) (NNI measured just before haulm destruction) and Giletto and Echeverría (2012) (NNI measured at tuber bulking) for establishing the relationship between RY and NNI.

\section{Results and Discussion}

\section{Total Crop Biomass Production and Nitrogen Concentration}

The $\mathrm{W}$ production during the growing season ranged from 0.33 to $12.71 \mathrm{t} \mathrm{DM} \mathrm{ha}^{-1}$ for Bintje and from 0.46 to $12.83 \mathrm{t} \mathrm{DM} \mathrm{ha}^{-1}$ for Charlotte depending on $\mathrm{N}$ applications rates, sampling dates, site and year (Table 2). Except for some situations (particularly at the beginning of the growing cycle), $\mathrm{W}$ generally increased with increasing $\mathrm{N}$ rates. This effect, not always statistically significant, was observed especially by comparing the non-fertilized treatments to $\mathrm{N}$ fertilized treatments.

The change of crop $\mathrm{N}$ concentration with time for Bintje in 1998 at Gembloux is shown as an example (Fig. 1). Crop $\mathrm{N}$ concentrations varied from a maximum of $5.23 \%$ of DM (observed for the $176 \mathrm{~N}$ rate at $22 / 6$ ) to a minimum of $0.88 \%$ of DM (observed for the $0 \mathrm{~N}$ rate at 20/8). The $\mathrm{N}$ concentration decreased as $\mathrm{W}$ increased during the growing season. This decline of $\mathrm{N}$ concentration with time reported by many studies (Justes et al. 1994; Duchenne et al. 1997; Bélanger et al. 2001; Li et al. 2012; Giletto and Echeverría 2012) corresponds to the dilution phenomenon which is mainly attributed to two processes. The first process corresponds to self-shading of leaves that induces a non-uniform leaf $\mathrm{N}$ concentration from the top of the canopy layers with high $\mathrm{N}$ concentration to the shaded layers with low $\mathrm{N}$ concentration (Lemaire et al. 1991; Pons and Pearcy 1994). The second process is the increase in the proportion of plant 
Table 2 Total biomass production for different potato trials conducted in Belgium with increasing N-fertilizer rates from 1997 to 2014 of cultivar Bintje or Charlotte

\begin{tabular}{|c|c|c|c|c|c|c|c|c|c|c|c|}
\hline \multirow{2}{*}{$\begin{array}{l}\text { Cultivar } \\
\text { Bintje }\end{array}$} & \multirow{2}{*}{$\begin{array}{l}\text { Sites } \\
\qquad \begin{array}{l}\text { Applied N } \\
\quad(\mathrm{kg} \mathrm{N} \mathrm{ha}\end{array}\end{array}$} & \multirow[t]{2}{*}{ Year } & \multirow[t]{2}{*}{ Date } & \multirow[t]{2}{*}{$\mathrm{DAE}^{\mathrm{a}}$} & \multicolumn{5}{|c|}{ Total biomass (t DM ha ${ }^{-1}$ ) } & \multirow[t]{2}{*}{$F$ test $^{\mathrm{b}}$} & \multirow[t]{2}{*}{$\mathrm{LSD}^{\mathrm{c}}$} \\
\hline & & & & & 0 & 75 & 113 & 150 & 188 & & \\
\hline & \multirow[t]{5}{*}{ Gembloux } & 1997 & $12 / 6$ & 21 & 0.79 & 1.15 & 1.14 & 1.2 & 1.25 & $*$ & 0.27 \\
\hline & & & $24 / 6$ & 33 & 2.17 & 3.08 & 3.38 & 3.33 & 3.31 & $* *$ & 0.68 \\
\hline & & & $3 / 7$ & 42 & 3.42 & 5.32 & 4.87 & 5.19 & 5.03 & $*$ & 1.09 \\
\hline & & & $16 / 7$ & 55 & 6.44 & 8.82 & 8.17 & 8.25 & 8.84 & $* *$ & 1.08 \\
\hline & & & $30 / 7$ & 69 & 9.37 & 12.36 & 10.85 & 12.34 & 12.71 & $*$ & 2.03 \\
\hline & \multicolumn{2}{|l|}{$\begin{array}{l}\text { Applied N } \\
\quad\left(\operatorname{kg~N~ha}^{-1}\right)\end{array}$} & & & 0 & 58 & 87 & 115 & 144 & & \\
\hline & \multirow[t]{3}{*}{ Masnuy } & \multirow[t]{3}{*}{1997} & $10 / 6$ & 22 & 1.08 & 0.89 & 1.06 & 1.08 & 0.84 & $\mathrm{~ns}$ & \\
\hline & & & $1 / 7$ & 43 & 4.05 & 5.63 & 4.51 & 4.67 & 4.95 & ns & \\
\hline & & & $24 / 7$ & 66 & 10.42 & 11.76 & 11.24 & 9.43 & 10.58 & ns & \\
\hline & \multicolumn{2}{|l|}{$\begin{array}{l}\text { Applied N } \\
\quad\left(\mathrm{kg} \mathrm{N} \mathrm{ha}^{-1}\right)\end{array}$} & & & 0 & 88 & 132 & 176 & 220 & & \\
\hline & \multirow[t]{3}{*}{ Gembloux } & \multirow[t]{3}{*}{1998} & $22 / 6$ & 33 & 0.93 & 1.78 & 1.66 & 1.82 & 1.66 & $* *$ & 0.46 \\
\hline & & & $1 / 7$ & 42 & 2.44 & 3.59 & 3.41 & 3.66 & 3.66 & $* *$ & 0.60 \\
\hline & & & $13 / 7$ & 54 & 5.16 & 8.23 & 6.48 & 6.58 & 7.08 & $* *$ & 1.31 \\
\hline & \multirow[t]{3}{*}{ Gouy } & 1998 & $24 / 6$ & 31 & 1.07 & 1.73 & 1.89 & 1.90 & 1.51 & $\mathrm{~ns}$ & \\
\hline & & & $7 / 7$ & 44 & 3.47 & 4.62 & 4.33 & 5.50 & 4.06 & $*$ & 1.27 \\
\hline & & & $15 / 7$ & 52 & 4.40 & 6.75 & 6.61 & 7.97 & 5.59 & $*$ & 1.97 \\
\hline & \multicolumn{2}{|l|}{$\begin{array}{l}\text { Applied N } \\
\quad\left(\mathrm{kg} \mathrm{N} \mathrm{ha}^{-1}\right)\end{array}$} & & & 0 & 119 & 170 & 221 & & & \\
\hline & Franière & 1999 & $28 / 7$ & 35 & 1.87 & 2.00 & 1.75 & 1.97 & & ns & \\
\hline & \multirow[t]{4}{*}{ Gembloux } & 1999 & $14 / 7$ & 21 & 0.53 & 0.50 & 0.40 & 0.44 & & ns & \\
\hline & & & $24 / 7$ & 31 & 1.66 & 2.12 & 1.72 & 2.00 & & ns & \\
\hline & & & $8 / 7$ & 45 & 4.44 & 5.39 & 5.50 & 5.38 & & $*$ & 0.73 \\
\hline & & & $19 / 7$ & 56 & 7.82 & 8.96 & 7.29 & 8.24 & & ns & \\
\hline & \multicolumn{2}{|l|}{$\begin{array}{l}\text { Applied N } \\
\quad\left(\mathrm{kg} \mathrm{N} \mathrm{ha}^{-1}\right)\end{array}$} & & & 0 & 112 & 160 & 208 & & & \\
\hline & Incourt & 1999 & $28 / 6$ & 35 & 2.64 & 2.53 & 2.48 & 2.34 & & ns & \\
\hline & \multicolumn{2}{|l|}{$\begin{array}{l}\text { Applied N } \\
\quad\left(\mathrm{kg} \mathrm{N} \mathrm{ha}^{-1}\right)\end{array}$} & & & 0 & 105 & 150 & 195 & & & \\
\hline & Marcq & 1999 & $1 / 7$ & 38 & 1.96 & 2.06 & 2.24 & 2.27 & & ns & \\
\hline & \multicolumn{2}{|l|}{$\begin{array}{l}\text { Applied N } \\
\quad\left(\mathrm{kg} \mathrm{N} \mathrm{ha}^{-1}\right)\end{array}$} & & & 0 & 88 & 125 & 163 & & & \\
\hline & Pontillas & 1999 & $28 / 6$ & 35 & 2.64 & 3.31 & 3.31 & 3.36 & & $*$ & 0.55 \\
\hline & \multicolumn{2}{|l|}{$\begin{array}{l}\text { Applied N } \\
\quad\left(\mathrm{kg} \mathrm{N} \mathrm{ha}^{-1}\right)\end{array}$} & & & 0 & 102 & 145 & 189 & & & \\
\hline & \multirow[t]{3}{*}{ Gembloux } & 2000 & $15 / 6$ & 32 & 1.75 & 2.78 & 2.38 & 2.71 & & $*$ & 0.68 \\
\hline & & & $29 / 6$ & 46 & 4.69 & 5.83 & 5.15 & 5.62 & & ns & \\
\hline & & & $13 / 7$ & 66 & 8.06 & 8.92 & 8.32 & 8.49 & & ns & \\
\hline & \multicolumn{2}{|l|}{$\begin{array}{l}\text { Applied N } \\
\quad\left(\mathrm{kg} \mathrm{N} \mathrm{ha}^{-1}\right)\end{array}$} & & & 0 & 102 & 145 & 189 & & & \\
\hline
\end{tabular}


Table 2 (continued)

\begin{tabular}{|c|c|c|c|c|c|c|c|c|c|c|c|c|}
\hline \multirow[t]{2}{*}{ Cultivar } & \multirow{2}{*}{$\frac{\text { Sites }}{\text { Roisin }}$} & \multirow{2}{*}{$\begin{array}{l}\text { Year } \\
2000\end{array}$} & \multirow{2}{*}{$\frac{\text { Date }}{19 / 6}$} & \multirow{2}{*}{$\frac{\mathrm{DAE}^{\mathrm{a}}}{44}$} & \multicolumn{6}{|c|}{ Total biomass (t DM ha $\left.{ }^{-1}\right)$} & \multirow{2}{*}{$\frac{F \text { test }^{\mathrm{b}}}{\mathrm{ns}}$} & \multirow[t]{2}{*}{$\mathrm{LSD}^{\mathrm{c}}$} \\
\hline & & & & & 2.43 & 2.88 & 2.68 & 2.60 & & & & \\
\hline & $\begin{array}{l}\text { Applied N } \\
\quad\left(\mathrm{kg} \mathrm{N} \mathrm{ha}^{-1}\right)\end{array}$ & & & & 0 & 100 & 140 & 180 & 240 & & & \\
\hline & Gembloux & 2004 & $14 / 6$ & 25 & 0.62 & 0.94 & 1.01 & 0.96 & 0.92 & & $\mathrm{~ns}$ & \\
\hline & & & $21 / 6$ & 32 & 1.88 & 2.49 & 2.52 & 2.45 & 2.37 & & $\mathrm{~ns}$ & \\
\hline & & & $28 / 6$ & 39 & 2.94 & 4.10 & 3.73 & 3.85 & 3.99 & & $*$ & 0.60 \\
\hline & & & $5 / 7$ & 46 & 4.19 & 5.53 & 5.78 & 5.46 & 6.08 & & $* *$ & 0.71 \\
\hline & & & $12 / 7$ & 53 & 5.67 & 7.29 & 6.82 & 6.98 & 7.47 & & $* * *$ & 0.48 \\
\hline & & & $19 / 7$ & 60 & 6.70 & 9.01 & 8.73 & 8.39 & 9.35 & & $* *$ & 1.32 \\
\hline & & & $27 / 7$ & 68 & 8.16 & 10.81 & 10.24 & 11.06 & 10.98 & & $*$ & 2.04 \\
\hline & $\begin{array}{l}\text { Applied N } \\
\quad\left(\mathrm{kg} \mathrm{N} \mathrm{ha}^{-1}\right)\end{array}$ & & & & 0 & 115 & 165 & 215 & 248 & & & \\
\hline & Gembloux & 2010 & $14 / 6$ & 25 & 0.65 & 0.83 & 0.71 & 0.77 & 0.68 & & ns & \\
\hline & & & $28 / 6$ & 34 & 3.10 & 3.19 & 3.42 & 3.22 & 3.42 & & $\mathrm{~ns}$ & \\
\hline & & & $5 / 7$ & 41 & 4.20 & 4.33 & 4.34 & 4.06 & 4.41 & & $\mathrm{~ns}$ & \\
\hline & & & $12 / 7$ & 48 & 5.12 & 5.50 & 5.24 & 5.43 & 5.27 & & ns & \\
\hline & & & $26 / 7$ & 62 & 7.19 & 7.72 & 8.15 & 7.07 & 7.80 & & ns & \\
\hline & $\begin{array}{l}\text { Applied N } \\
\quad\left(\mathrm{kg} \mathrm{N} \mathrm{ha}^{-1}\right)\end{array}$ & & & & 0 & 98 & 140 & 182 & 210 & & & \\
\hline & Gembloux & 2011 & $14 / 6$ & 27 & 1.44 & 1.46 & 1.27 & 1.55 & 1.36 & & $\mathrm{~ns}$ & \\
\hline & & & $6 / 7$ & 49 & 5.55 & 5.15 & 5.41 & 5.37 & 5.53 & & ns & \\
\hline & & & $20 / 7$ & 63 & 8.26 & 8.25 & 8.04 & 8.88 & 8.53 & & $\mathrm{~ns}$ & \\
\hline & & & $25 / 7$ & 68 & 8.77 & 10.22 & 8.86 & 9.42 & 9.30 & & $\mathrm{~ns}$ & \\
\hline & $\begin{array}{l}\text { Applied N } \\
\quad\left(\mathrm{kg} \mathrm{N} \mathrm{ha}^{-1}\right)\end{array}$ & & & & 0 & 50 & 100 & 150 & 200 & 250 & & \\
\hline & Gembloux & 2012 & $27 / 6$ & 26 & 1.02 & 1.10 & 1.21 & 1.37 & 1.28 & 1.32 & ns & \\
\hline & & & $4 / 7$ & 33 & 1.91 & 2.83 & 2.83 & 2.75 & 3.25 & 2.97 & $* *$ & 0.55 \\
\hline & & & $11 / 7$ & 40 & 3.25 & 3.41 & 4.00 & 4.28 & 4.29 & 4.66 & $* * *$ & 0.41 \\
\hline & & & $25 / 7$ & 54 & 5.82 & 7.31 & 6.06 & 7.54 & 5.40 & 6.21 & $\mathrm{~ns}$ & \\
\hline & Gembloux & 2013 & $19 / 6$ & 13 & 0.33 & 0.44 & 0.41 & 0.44 & 0.52 & 0.43 & ns & \\
\hline & & & $26 / 6$ & 20 & 1.00 & 1.41 & 1.16 & 1.45 & 1.23 & 1.29 & $\mathrm{~ns}$ & \\
\hline & & & $11 / 7$ & 35 & 3.79 & 4.33 & 4.35 & 4.64 & 5.04 & 4.50 & ns & \\
\hline & & & $23 / 7$ & 47 & 5.19 & 6.67 & 7.14 & 7.21 & 7.13 & 6.76 & $*$ & 1.36 \\
\hline & Gembloux & 2014 & $18 / 6$ & 29 & 2.51 & & 2.91 & & 2.85 & 2.67 & ns & \\
\hline & & & $3 / 7$ & 44 & 5.99 & & 5.99 & & 6.75 & 6.76 & ns & \\
\hline & & & $30 / 7$ & 71 & 10.23 & & 11.70 & & 11.10 & 11.77 & $\mathrm{~ns}$ & \\
\hline \multirow[t]{5}{*}{ Charlotte } & $\begin{array}{l}\text { Applied N } \\
\quad\left(\mathrm{kg} \mathrm{N} \mathrm{ha}^{-1}\right)\end{array}$ & & & & 0 & 84 & 120 & 156 & & & & \\
\hline & Gembloux & 1999 & $6 / 7$ & 42 & 3.07 & 3.43 & 4.22 & 4.32 & & & ns & \\
\hline & & & $22 / 7$ & 58 & 5.79 & 8.47 & 7.70 & 8.29 & & & $\mathrm{~ns}$ & \\
\hline & $\begin{array}{l}\text { Applied N } \\
\quad\left(\mathrm{kg} \mathrm{N} \mathrm{ha}^{-1}\right)\end{array}$ & & & & 0 & 100 & 140 & 180 & 210 & & & \\
\hline & Gembloux & 2010 & $17 / 6$ & 15 & 0.88 & 1.04 & 1.03 & 0.83 & 0.96 & & $\mathrm{~ns}$ & \\
\hline
\end{tabular}


Table 2 (continued)

\begin{tabular}{|c|c|c|c|c|c|c|c|c|c|c|c|c|}
\hline \multirow[t]{2}{*}{ Cultivar } & \multirow[t]{2}{*}{ Sites } & \multirow[t]{2}{*}{ Year } & \multirow{2}{*}{$\frac{\text { Date }}{1 / 7}$} & \multirow{2}{*}{$\frac{\mathrm{DAE}^{\mathrm{a}}}{29}$} & \multicolumn{6}{|c|}{ Total biomass (t DM ha ${ }^{-1}$ ) } & \multirow{2}{*}{$\frac{F \text { test }^{\mathrm{b}}}{\mathrm{ns}}$} & \multirow[t]{2}{*}{$\mathrm{LSD}^{\mathrm{c}}$} \\
\hline & & & & & 3.34 & 4.01 & 3.71 & 3.30 & 3.35 & & & \\
\hline & & & $8 / 7$ & 36 & 4.72 & 5.13 & 4.38 & 5.07 & 5.22 & & ns & \\
\hline & & & $15 / 7$ & 43 & 5.83 & 5.91 & 6.11 & 5.19 & 5.93 & & ns & \\
\hline & & & $19 / 7$ & 47 & 5.36 & 6.08 & 6.05 & 5.95 & 6.16 & & ns & \\
\hline & \multicolumn{2}{|l|}{$\begin{array}{l}\text { Applied N } \\
\quad\left(\mathrm{kg} \mathrm{N} \mathrm{ha}^{-1}\right)\end{array}$} & & & 0 & 84 & 120 & 156 & 180 & & & \\
\hline & \multirow[t]{4}{*}{ Gembloux } & 2011 & $20 / 6$ & 33 & 2.36 & 2.64 & 2.32 & 2.77 & 2.95 & & ns & \\
\hline & & & $4 / 7$ & 47 & 5.17 & 5.59 & 5.32 & 6.03 & 5.19 & & ns & \\
\hline & & & $11 / 7$ & 54 & 6.45 & 7.60 & 6.37 & 7.57 & 6.47 & & ns & \\
\hline & & & $18 / 7$ & 61 & 8.51 & 9.64 & 9.40 & 9.68 & 10.13 & & ns & \\
\hline & \multicolumn{2}{|l|}{$\begin{array}{l}\text { Applied N } \\
\quad\left(\mathrm{kg} \mathrm{N} \mathrm{ha}^{-1}\right)\end{array}$} & & & 0 & 50 & 100 & 150 & 200 & 250 & & \\
\hline & \multirow[t]{4}{*}{ Gembloux } & \multirow[t]{4}{*}{2012} & $27 / 6$ & 27 & 1.27 & 1.35 & 1.46 & 1.49 & 1.50 & 1.46 & $\mathrm{~ns}$ & \\
\hline & & & $2 / 7$ & 32 & 2.09 & 2.38 & 2.74 & 2.64 & 2.69 & 2.63 & ns & \\
\hline & & & $9 / 7$ & 39 & 4.09 & 4.54 & 4.10 & 4.54 & 4.57 & 4.30 & ns & \\
\hline & & & $16 / 7$ & 48 & 5.01 & 4.80 & 5.50 & 5.47 & 5.96 & 5.49 & ns & \\
\hline & \multirow[t]{4}{*}{ Gembloux } & \multirow[t]{4}{*}{2013} & $17 / 6$ & 13 & 0.46 & 0.58 & 0.63 & 0.53 & 0.61 & 0.54 & $* *$ & 0.09 \\
\hline & & & $24 / 6$ & 20 & 1.03 & 1.37 & 1.51 & 1.43 & 1.70 & 1.36 & $* *$ & 0.31 \\
\hline & & & $1 / 7$ & 27 & 2.19 & 2.53 & 2.91 & 2.94 & 3.27 & 2.98 & $* *$ & 0.51 \\
\hline & & & $15 / 7$ & 41 & 5.34 & 6.70 & 6.91 & 7.41 & 6.96 & 6.94 & $* * *$ & 0.68 \\
\hline & \multirow[t]{3}{*}{ Gembloux1 } & \multirow[t]{3}{*}{2014} & $16 / 6$ & 30 & 2.42 & & 2.41 & & 2.69 & 2.53 & $\mathrm{~ns}$ & \\
\hline & & & $26 / 6$ & 44 & 5.43 & & 5.73 & & 5.74 & 5.87 & ns & \\
\hline & & & $28 / 7$ & 72 & 9.45 & & 11.16 & & 11.67 & 12.83 & ns & \\
\hline & \multirow[t]{4}{*}{ Gembloux2 } & \multirow[t]{4}{*}{2014} & $24 / 6$ & 36 & 3.31 & & 3.87 & & & 3.53 & ns & \\
\hline & & & $8 / 7$ & 51 & 6.02 & & 7.22 & & & 7.24 & $*$ & 0.89 \\
\hline & & & $15 / 7$ & 58 & 7.22 & & 7.88 & & & 8.91 & ns & \\
\hline & & & $23 / 7$ & 66 & 8.92 & & 10.89 & & & 10.03 & ns & \\
\hline
\end{tabular}

Bold numbers represents total biomass used for the validation

$D A E$ days after emergence; ns indicates no significance $(p>0.05) ; L S D$ least significant difference calculated if the $F$ test indicated significant difference among total biomass ( $\mathrm{t}$ of dry matter ha ${ }^{-1}$ )

$* F$ test indicating statistical significance at $p \leq 0.05 ; * * F$ test indicating statistical significance at $p \leq 0.01$; $* * * F$ test indicating statistical significance at $p \leq 0.001$

structural and storage tissues with a lower nitrogen concentration (Caloin and Yu 1984). Crop $\mathrm{N}$ concentration varied significantly with $\mathrm{N}$ rates; higher $\mathrm{N}$ rates mostly resulted in higher $\mathrm{N}$ concentrations (Fig. 1).

\section{Determination of the Critical Nitrogen Dilution Curve for Cultivar Bintje}

Among the sites and years used to establish the critical dilution curve, 16 sampling dates (between 21 and 69 DAE) for Bintje met the previously defined statistical criteria. Each of these sampling dates provided a point of $\mathrm{Nc}$ concentration for a given $\mathrm{W}$ (Table 3). 


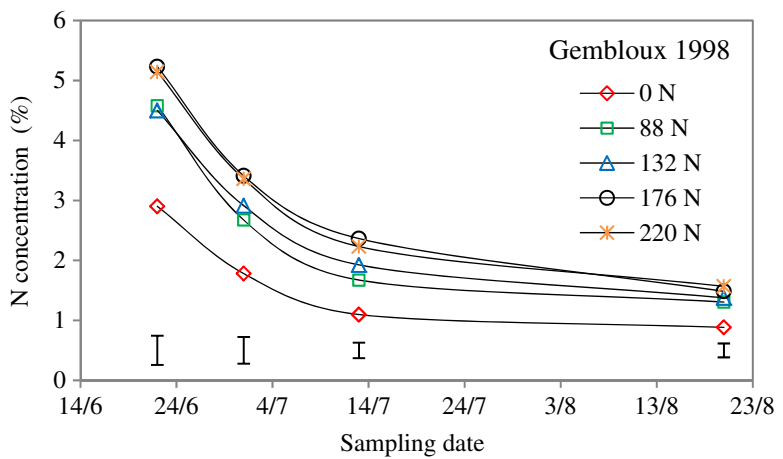

Fig. 1 Changes of nitrogen concentration in total biomass (W, expressed in \% of dry matter) with time for potato cultivar Bintje under different $\mathrm{N}$ rates $\left(\mathrm{kg} \mathrm{N} \mathrm{ha}^{-1}\right)$ at the site Gembloux in 1998. The vertical bars represent LSD values $(p \leq 0.05)$ at each plant sampling date

As illustrated in Fig. 2, the allometric equation obtained for cv. Bintje was

$$
\mathrm{Nc}(\%)=5.37 \mathrm{~W}^{-0.45}
$$

The model accounted for $86 \%$ of the total variance. The $95 \%$ confidence interval of the mean was $1.30 \mathrm{~N}$ (in \% of DM) for a W of $1.15 \mathrm{tDM} \mathrm{ha}^{-1}$ and $0.54 \mathrm{~N}$ (in \% of DM) for a total biomass of $10.85 \mathrm{t} \mathrm{DM} \mathrm{ha}^{-1}$.

Table 3 Critical nitrogen concentration data points selected for the calibration of the Belgian critical nitrogen dilution curve for cultivar Bintje

\begin{tabular}{llllll}
\hline Sites & Sampling dates & DAE & Applied N & Total biomass & Nc concentration \\
\hline Gembloux & 12 June 1997 & 21 & 75 & 1.15 & 4.45 \\
Gembloux & 24 June 1997 & 33 & 75 & 3.08 & 3.53 \\
Gembloux & 3 July 1997 & 42 & 75 & 5.32 & 2.79 \\
Gembloux & 16 July 1997 & 55 & 75 & 8.82 & 1.86 \\
Gembloux & 30 July 1997 & 69 & 113 & 10.85 & 1.55 \\
Gembloux & 22 June 1998 & 33 & 88 & 1.78 & 4.58 \\
Gembloux & 1 July 1998 & 42 & 88 & 3.59 & 2.67 \\
Gembloux & 13 July 1998 & 54 & 88 & 8.23 & 1.67 \\
Pontillas & 28 June 1999 & 35 & 88 & 3.31 & 3.29 \\
Gembloux & 28 June 2004 & 39 & 100 & 4.10 & 2.96 \\
Gembloux & 5 July 2004 & 46 & 100 & 5.53 & 2.22 \\
Gembloux & 12 July 2004 & 53 & 240 & 7.47 & 2.48 \\
Gembloux & 19 July 2004 & 60 & 100 & 9.01 & 1.57 \\
Gembloux & 27 July 2004 & 68 & 100 & 10.81 & 1.47 \\
Gembloux & 4 July 2012 & 33 & 50 & 2.83 & 3.47 \\
Gembloux & 11 July 2012 & 40 & 250 & 4.66 & 3.40 \\
\hline
\end{tabular}

Applied nitrogen $(\mathrm{N})$ in $\mathrm{kg} \mathrm{ha}^{-1}$, total biomass expressed in $\mathrm{t}$ of dry matter ha ${ }^{-1}$ and critical nitrogen $(\mathrm{Nc})$ concentration expressed in percentage of dry matter

$D A E$ day after emergence of the crop 


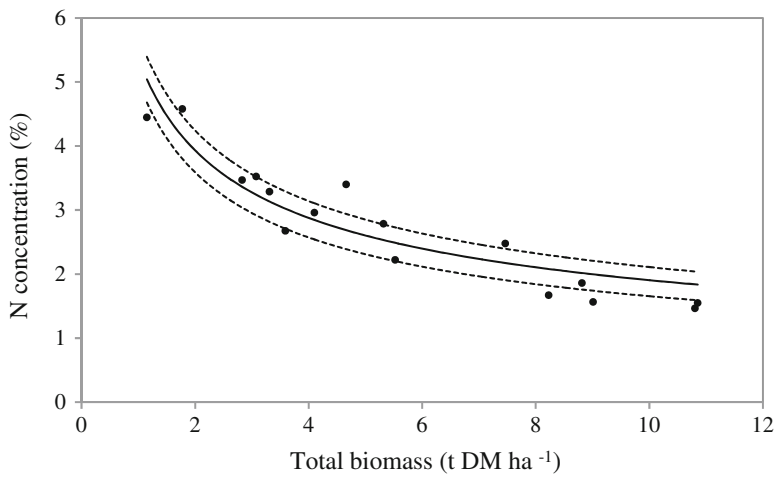

Fig. 2 Critical nitrogen $(\mathrm{Nc})$ concentration data points used to define the critical $\mathrm{N}$ dilution curve of potato for cultivar Bintje in Belgium. The solid line represents the critical $\mathrm{N}$ dilution curve with the relation $\mathrm{Nc}$ $(\%)=5.37 \mathrm{~W}^{-0.45}\left(R^{2}=0.86\right)$. The dotted lines represent the confidence band $(p=0.95)$ for mean prediction

\section{Comparison with Available Critical Nitrogen Dilution Curves for Potato Crop}

Figure 3 shows that the Nc curve defined in this study was very similar to the reference curve of Greenwood et al. (1990) and clearly above the reference curve established by Duchenne et al. (1997). Taking into account the curves of Bélanger et al. (2001), the Belgian curve is relatively similar to the one established for cv. Shepody (particularly from medium $\mathrm{W}$ productions) and above the one established for cv. Russet Burbank. Comparing the curve obtained by Giletto and Echeverría (2012), the Belgian curve is slightly lower, particularly for the medium and the higher $\mathrm{W}$ productions.

In this study, the coefficient $a$ (5.37) for the dilution curve equation was very similar to the ones of Greenwood et al. (1990) (5.36) and Giletto and Echeverría (2012) (5.30). Similarly, the coefficient of dilution $b(0.45)$ was close to the coefficient obtained by

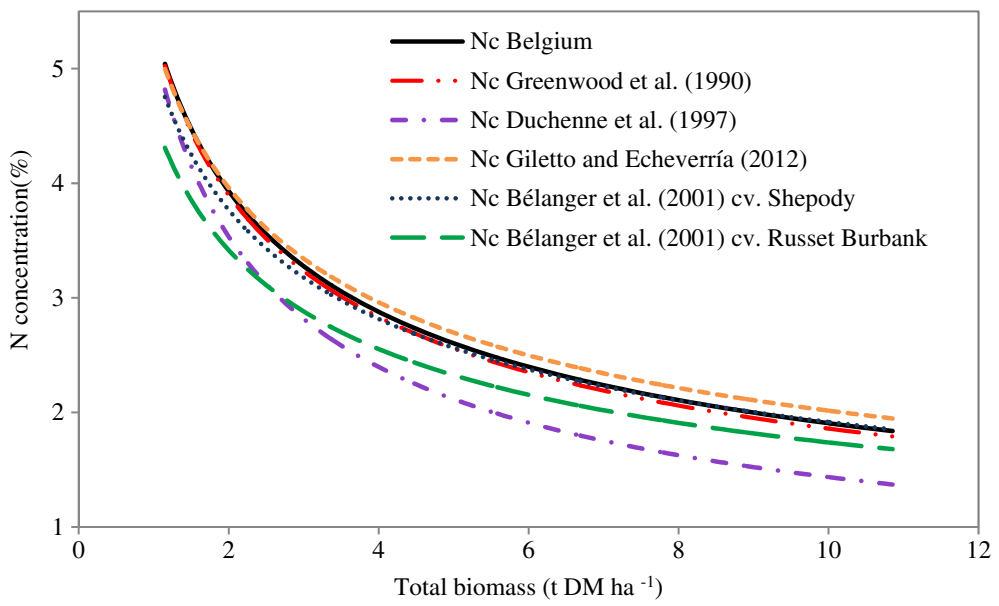

Fig. 3 Comparison of different critical nitrogen curves for potato. The full black line represents the Belgian critical $\mathrm{N}$ curve (this study) $\left(\mathrm{Nc}(\%)=5.37 \mathrm{~W}^{-0.45}\right.$ for cv. Bintje). The other curves represent the proposed reference by Duchenne et al. (1997) $\left(\mathrm{Nc}(\%)=5.21 \mathrm{~W}^{-0.56}\right)$, by Greenwood et al. (1990) $(\mathrm{Nc}(\%)=$ $\left.5.36 \mathrm{~W}^{-0.46}\right)$, by Giletto and Echeverría (2012) $\left(\mathrm{Nc}(\%)=5.30 \mathrm{~W}^{-0.42}\right.$ ) and by Bélanger et al. (2001) (for cv. Shepody Nc $(\%)=5.04 \mathrm{~W}^{-0.42}$ and for cv. Russet Burbank Nc $(\%)=4.57 \mathrm{~W}^{-0.42}$ ) 
Greenwood et al. (1990) (0.46) and Giletto and Echeverría (2012) and Bélanger et al. (2001) (0.42).

The reasons for the difference observed between the coefficients of the Belgian curve and the reference curves of Duchenne et al. (1997) and Bélanger et al. (2001) for cv. Russet Burbank could be related to various factors including differences in cultivars, climatic conditions and field management. Duchenne et al. (1997) established the Nc curve on the basis of three experimental years on two cultivars Bintje and Kaptah Vandel. The curve was then validated for Saturna, El Kana and Russet Burbank in loamy soils and for Bintje in calcareous clay and calcareous soils (Chambenoit et al. 2004). The critical points obtained for each cultivar were close to the established Nc curve for Bintje and Kaptah Vandel. Chambenoit et al. (2004) stated that varietal differences may exist but were not detectable given the precision level of the used experimental design. The cultivar differences seem mainly related to the earliness of each cultivar that determines the maximum production of dry matter and therefore the dilution of the nitrogen in the plant biomass (Chambenoit et al. 2004). Vos (1997) reported that the relationship between $\mathrm{N}$ uptake and biomass accumulation should be different for genotypes of different earliness. Giletto and Echeverría (2015) found that cultivars with shorter growing season (cultivars Innovator and Gem Russet) had lower plant $\mathrm{N}$ concentration for a same level of total biomass than cultivars with longer growing seasons (cultivars Umatilla Russet, Bannock Russet and Markies Russet). Contrary to Giletto and Echeverría (2015), Bélanger et al. (2001) found greater N concentration for the cultivar Shepody with shorter season than for Russet Burbank. Giletto and Echeverría (2015) reported different statistical value in the coefficient $b$ between the tested cultivars but showed no statistical differences in coefficient $a$. However, Bélanger et al. (2001), reported different values of coefficients $a$ and similar values of coefficient $b$ for Shepody and Russet Burbank. According to Bélanger et al. (2001), the observed difference in the coefficient $a$ was caused by differences in plant density. The cultivar with greater plant density had smaller plants with greater $\mathrm{N}$ concentration than the cultivars with low plant density. Similar $b$ coefficients indicated that both cultivars had similar N dilution (Bélanger et al. 2001). In our study, the plant density was different according to the seed size used.

Bélanger et al. (2001) reported also different parameters $a$ and $b$ of the Nc curve for both studied cultivars according to the water regime. The $\mathrm{N}$ concentration at a given level of total biomass, primarily for Russet Burbank, was lower without than with irrigation. The water deficiency decreased $\mathrm{N}$ uptake and therefore indirectly created conditions of $\mathrm{N}$ deficiency (Bélanger et al. 2001). The curve of Duchenne et al. (1997) was established under growing conditions for which water was not limiting growth. In this study, the Nc curve for Bintje was established for Belgian climate and soil conditions for which temporary water deprivation may occur. The climate in Belgium is a temperate maritime climate with cool summers and moderate winters which is similar to the climate of the north of France, Scotland and the Netherlands. According to Lemaire and Gastal (1997), the relationship between Nc concentration and crop mass does not vary considerably with major environmental factors others than those affecting soil N supply. Ziadi et al. (2010) stated that climatic conditions could explain part of the difference observed between the Canadian Nc curve of spring wheat and the French curve of winter wheat developed by Justes et al. (1994). 
The observed difference with the Nc curve of Duchenne et al. (1997) could also be due to their applied statistical method which corresponds to the classification of the $\mathrm{W}$ values using the Newman and Keuls test for $p=0.10$. The range of plant weights used for the calibration of the Nc curves could also have influenced the relationship between $\mathrm{Nc}$ and W. Contrary to Bélanger et al. (2001), who limited the data set to $\mathrm{W}$ less than $6 \mathrm{t}$ $\mathrm{DM} \mathrm{ha}{ }^{-1}$, the $\mathrm{W}$ used in this study for the establishment of the curve ranged from 1.15 to $10.85 \mathrm{t} \mathrm{DM} \mathrm{ha}^{-1}$ corresponding to the period from June to July. Greenwood et al. (1990), Duchenne et al. (1997) and Giletto and Echeverría (2012) based their estimation on data with a range of $\mathrm{W}$ up to $12-15 \mathrm{t} \mathrm{DM} \mathrm{ha}^{-1}$.

\section{Validation of the Critical Nitrogen Dilution Curve for Cultivars Bintje and Charlotte}

The crop is considered in non-limiting $\mathrm{N}$ conditions if the actual $\mathrm{N}$ concentration is higher than the Nc concentration required for maximum growth rate. The crop is in limiting growth condition if the actual $\mathrm{N}$ concentration is below the $\mathrm{Nc}$ curve. In the validation data set for $\mathrm{cv}$. Bintje (see Table 1), 5 points were in limiting $\mathrm{N}$ conditions and 12 points in non-limiting $\mathrm{N}$ conditions (Fig. 4). All data points identified as limiting $\mathrm{N}$ conditions were under the $\mathrm{Nc}$ curve and all the data points identified as non-limiting $\mathrm{N}$ conditions (except 1) were above the curve (Fig. 4). These observations tend to confirm that the Nc curve can be used for the discrimination between the limiting and non-limiting $\mathrm{N}$ conditions and the determination of CNS for the cv. Bintje in Belgian conditions.

Following the same approach, 4 limiting $\mathrm{N}$ conditions and 5 non-limiting $\mathrm{N}$ conditions were identified for $\mathrm{cv}$. Charlotte. As for cv. Bintje, all the limiting $\mathrm{N}$ conditions were under the Nc curve and all the non-limiting $\mathrm{N}$ conditions (except 1) were above the curve. According to the limited number of points for validation, the Nc curve could also be used for the discrimination between limiting and non-limiting $\mathrm{N}$ conditions for cv. Charlotte. But since Charlotte is an earlier cultivar than Bintje and, as mentioned before, the earliness of the genotype is a factor of intra-specific variability in potato for the relationship between $\mathrm{N}$ concentration and biomass, thus when establishing the Nc curve, the cultivar factor should be taken into account. In this study, due to the limited number of data points, a cultivar difference was not detectable. A study

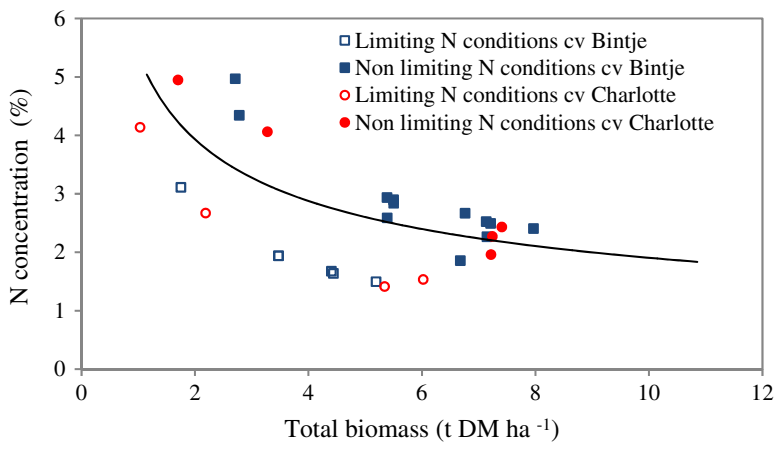

Fig. 4 Validation of the Belgian critical $\mathrm{N}$ curve using data from potato cultivars Bintje and Charlotte under limiting and non limiting $\mathrm{N}$ growth conditions. The solid line represents the predicted critical $\mathrm{N}$ dilution curve with the relation $\mathrm{Nc}(\%)=5.37 \mathrm{~W}^{-0.45}$ 
based on a larger data set for cv. Charlotte is therefore needed in order to be able to draw more definitive conclusions.

\section{Nitrogen Nutrition Index and Its Relation to Relative Yield}

The NNI was calculated for each plant sampling date. The NNI in this study ranged from 0.39 to 1.53 (data not shown). As an example, the NNI values over three plant sampling dates at Gembloux in 2014 are given in Fig. 5. Values of NNI $\geq 1$ indicate that the crop is non-limiting for $\mathrm{N}$, whereas values of $\mathrm{NNI}<1$ indicate $\mathrm{N}$ deficiency (Duchenne et al. 1997). Contrary to the maximum $\mathrm{N}$ treatment $(250 \mathrm{~N})$, the data points for the non-fertilized treatment were clearly under the reference of 1 indicating $\mathrm{N}$ deficiency, whatever the sampling date. The NNI values for the 100 and $200 \mathrm{~N}$ treatments were over this reference at the first sampling date but dropped below this threshold at the second sampling date for the $100 \mathrm{~N}$ treatment and at the last sampling date for the $200 \mathrm{~N}$ treatment.

The relationship between NNI and RY expressed by a quadratic plateau function accounted for 79,75 and $70 \%$ of the variation considering the three different periods of plant sampling for the calculation of NNI, i.e. respectively, the mean of all the sampling dates, the mean of sampling between 20 and 55 DAE and the last sampling date closest to harvest (Fig. 6). Based on this relationship, the potato RY reached a plateau for a determined NNI value. This value corresponds to the joint point of the quadratic phase and the plateau phase for each of the three curves and was equal to 1.1 (Fig. 6a), 1.16 (Fig. 6b) and 0.97 (Fig. 6c) depending on the considered plant-sampling period. With decreasing NNI value below this joint point, the RY decreased (Fig. 6). This confirms the link between $\mathrm{N}$ uptake and yield of potato and thus the relevancy of the Nc model and the resulting NNI for forecasting actual yield with respect to potential yield (Chambenoit et al. 2004).

The relationship between NNI and RY, however, varied with the periods of plant sampling for NNI determination (Fig. 6). The maximum RY obtained was the same for the three functions (0.97), but the equation of RY corresponding to NNI below the joint point was different. This joint point is important for determining the threshold value under which the crop nitrogen status is considered as deficient with respect to

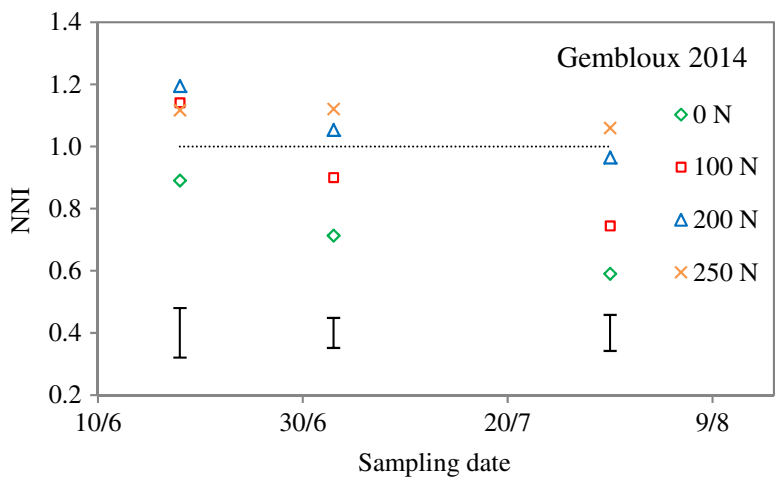

Fig. 5 Nitrogen Nutrition Index (NNI) of three sampling dates for increasing $\mathrm{N}$ rates $\left(\mathrm{kg} \mathrm{N}^{-1}\right)$ at the site of Gembloux in 2014 for cultivar Bintje. The dotted horizontal line represents an NNI of 1.0. The vertical bars represent LSD values $(p \leq 0.05)$ at each plant sampling date 

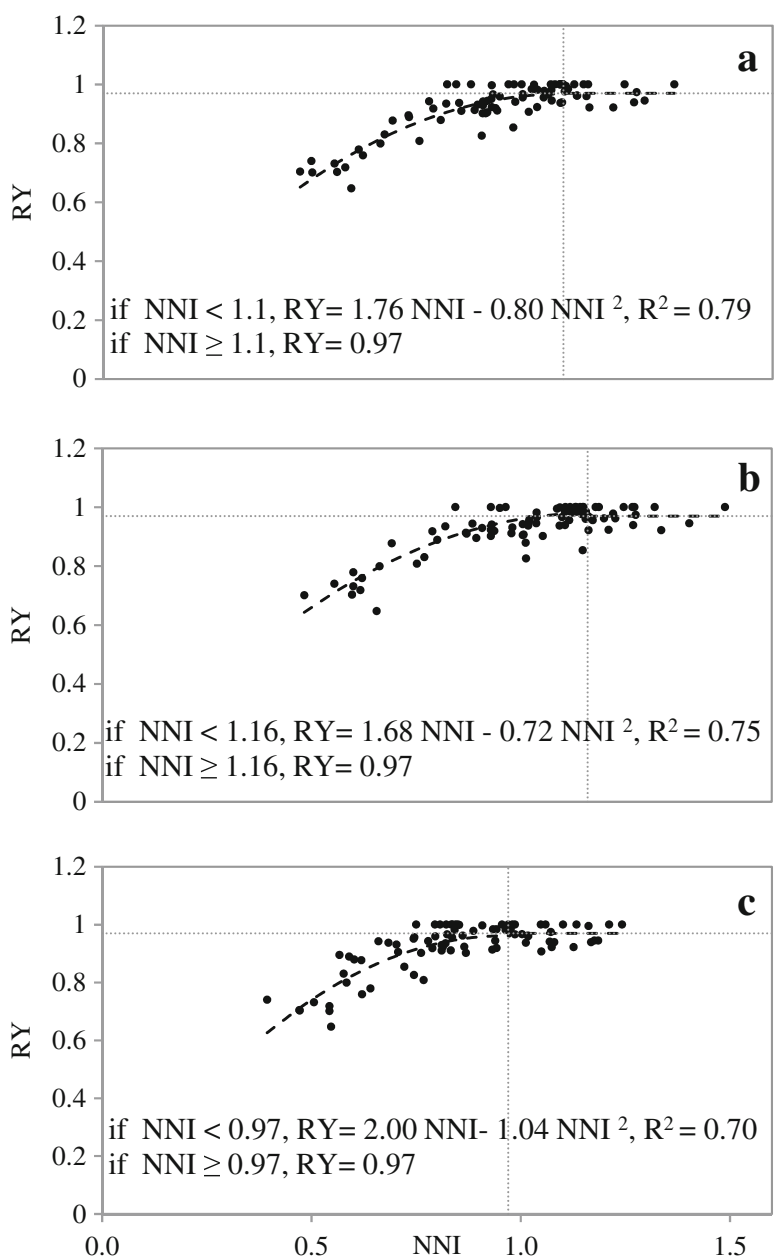

Fig. 6 Relationship between relative yield (RY) measured at harvest and nitrogen nutrition index (NNI) for cultivar Bintje measured across all the sampling dates (a), across the period of 20 and 55 DAE (b) and for the last sampling date (c). The vertical bars indicate the joint point for each curve, and the horizontal bars indicate the plateau of the curve

maximum potential yield. The NNI reference value of 1 given by Duchenne et al. (1997) corresponds to the optimum CNS required to achieve the maximum growth rate. Chambenoit et al. (2004) reported values of NNI between 1.1 and 1.2 to maximize the tuber yield. In this study, the reference value of NNI was slightly higher, as in Chambenoit et al. (2004), for Fig. 6a, b with values of 1.1 and 1.16 (when considering all the plant sampling dates or the period between 20 and 55 DAE) and similar for Fig. $6 \mathrm{c}$ with value of 0.97 (when considering the latest sampling date) compared to the reference value of 1 . The period between 20 and $55 \mathrm{DAE}$ has been demonstrated as the optimal period for the assessment of the CNS, according to a previous study by Olivier et al. (2006). Consequently, in this study, we consider the reference NNI value of 1.16 (Fig. 6b), under which the CNS is considered as deficient during the optimal period for CNS assessment. 


\section{Conclusion}

A Nc dilution curve $\left(\mathrm{Nc}(\%)=5.37 \mathrm{~W}^{-0.45}\right)$ was developed for potato for cv. Bintje under the Belgian conditions. The Belgian Nc dilution curve was different from the one developed for potato in France but similar to the one developed in Scotland and the Netherlands. The usefulness of the Belgian Nc dilution curve for cv. Charlotte was not fully verified since the validation considered only a limited data set and cultivar difference is reported as a factor of variability of the Nc curve. The Belgian Nc curve and the resulting NNI adequately identified situations of limiting and non-limiting N nutrition and could be used to establish the potato CNS and to predict the final yield. A reference NNI value of 1.16 was established as the threshold value to be achieved during the optimal period for CNS assessment, under which threshold the CNS is considered as deficient.

However, establishing the NNI at field level requires destructive and chemical analysis and is not appropriate for a quick assessment of CNS. The NNI can be used as a reference for calibrating other non-invasive methods for a quick and easy in-season monitoring of CNS (Goffart et al. 2008).

Acknowledgments This study was funded by the federal Ministry of Agriculture (DGA, Brussels) and the regional Walloon (SPW, DGO3, Namur) Public Service in Belgium. Special thanks are addressed to the different technicians, workers and students of the potato service at the Walloon Agriculture Research Centre (Crops Production Systems Unit) for their valuable contribution to the trials.

The statistical assistance of Elena Pitchugina, Viviane Planchon and Yves Brostaux was gratefully acknowledged.

\section{References}

Bélanger G, Gastal F (2000) Nitrogen utilization by forage grasses. Can J Plant Sci 80:11-20

Bélanger G, Walsh JR, Richards JE, Milburn PH, Ziadi N (2001) Critical nitrogen curve and nitrogen nutrition index for potato in eastern Canada. Am J Potato Res 78(5):355-364

Brook AJ, Woodcock BA, Sinka M, Vanbergen AJ (2008) Experimental verification of suction sampler capture efficiency in grasslands of differing vegetation height and structure. J App Ecol 45(5):1357-1363

Caloin M, Yu O (1984) Analysis of the time course of change in nitrogen content in Dactylis glomerata L.using a model of plant growth. Annals Bot 54:69-76

Chambenoit C, Laurent F, Machet JM, Boizard H (2004) In : MacKerron DKL, Haverkort AJ (Eds) Decision support systems in potato production, Wageningen, pp 55-67.

Colnenne C, Meynard JM, Reau R, Justes E, Merrien A (1998) Determination of a critical nitrogen dilution curve for winter oilseed rape. Annals Bot 81:311-317

Duchenne T, Machet JM, Martin M (1997) In: Lemaire G (ed) Diagnosis of the nitrogen status in crops. Springer, Berlin, pp 119-130

Giletto CM, Echeverría HE (2012) Critical nitrogen dilution curve for processing potato in Argentinean humid pampas. Am J Potato Res 89:102-110. doi:10.1007/s12230-011-9226-Z, Accessed 02 January 2015

Giletto CM, Echeverría HE (2015) Critical nitrogen dilution curve in processing potato cultivars. Am J Potato Res 6:3144-3156, http://file.scirp.org/pdf/AJPS_2015121114375992.pdf. Accessed 04 July 2016

Goffart JP, Olivier M, Frankinet M (2008) Potato crop nitrogen status assessment to improve N fertilization management and efficiency: past-present-future. Potato Res 51(3-4):355-383

Greenwood DJ, Lemaire G, Gosse G, Cruz P, Draycott A, Neeteson JJ (1990) Decline in percentage N of C3and C4 crops with increasing plant mass. Ann Bot 66:425-436

Justes E, Mary B, Meynard JM, Machet JM, Thelier-Huché L (1994) Determination of a critical nitrogen dilution curve for winter wheat crops. Annals Bot 74(4):397-407 
Lemaire G, Gastal F (1997) N uptake and distribution in plant canopies. In: Lemaire G (ed) Diagnosis of the nitrogen status in crops. Springer, Heidelberg, pp 3-43

Lemaire G, Gastal F (2009) Quantifying crop responses to nitrogen deficiency and avenues to improve nitrogen use efficiency. In: Sadras VO, Calderini DF (eds) Crop physiology: applications for genetic improvement and agronomy. Elsevier, Burlington, pp 171-211

Lemaire G, Salette J (1984) Relation entre dynamique de croissance et dynamique de prélèvement d'azote pour un peuplement de graminées fourragères. I.-Etude de l'effet du milieu. Agron 4(5):423-430

Lemaire G, Onillon B, Gosse G, Chartier M, Allirand JM (1991) Nitrogen distribution within a lucerne canopy during regrowth: relation with light distribution. Annals Bot 68:483-488

Li W, He P, Jin J (2012) Critical nitrogen curve and nitrogen nutrition index for spring maize in north east China. J Plant Nutri 35(11):1747-176

Olivier M, Goffart JP, Ledent JF (2006) Threshold value for chlorophyll meter as decision tool for nitrogen management of potato. Agronomy Journal 98(3):496-506

Plénet D, Lemaire G (2000) Relationships between dynamics of nitrogen uptake and dry matter accumulation in maize crops. Determination of critical N concentration. Plant Soil 216:65-82

Pons TL, Pearcy RW (1994) Nitrogen reallocation and photosynthetic acclimation in response to partial shading in soybean plants. Physiol Plantarum 92:636-644

Sheehy JE, Dionora MJA, Mitchell PL, Peng S, Cassman KG, Lemaire G, Williams RL (1998) Critical nitrogen concentrations: implications for high-yielding rice (Oryza sativa L.) cultivars in the tropics. Field Crop Res 59:31-41

Shenk J, Westerhaus M (1993) Monograph: Analysis of agriculture and food products by Near Infrared Reflectance Spectroscopy. Infrasoft International, Port Matilda, $103 p$

Ulrich A (1952) Physiological bases for assessing the nutritional requirements of plants. Annu Rev of Plant Physiol 3:207-228

Vos J (1997) The nitrogen response of potato (Solanum tuberosum L.) in the field: nitrogen uptake and yield, harvest index and nitrogen concentration. Potato Res 40:237-248

Ziadi N, Brassard M, Bélanger G, Cambouris AN, Tremblay N, Nolin MC, Claessens A, Parent LE (2008) Critical nitrogen curve and nitrogen nutrition index for corn in eastern Canada. Agron J 100(2):271-276

Ziadi N, Bélanger G, Claessens A, Lefebvre L, Cambouris AN, Tremblay N, Nolin MC, Parent LE (2010) Determination of a critical nitrogen dilution curve for spring wheat. Agron J 102:241-250 